\title{
Etymology of the Genus Name Nostoc (Cyanobacteria)
}

\author{
MALCOLM POTTS* \\ Department of Biochemistry and Anaerobic Microbiology, Virginia Polytechnic Institute and State University, \\ Blacksburg, Virginia 24061
}

\begin{abstract}
The word Nostoch was invented by the 15th century scientist, philosopher, and alchemist Aureolus Philippus Theophrastus Bombastus von Hohenheim (Paracelsus) to describe the gelatinous colonies of the ubiquitous terrestrial cyanobacterium Nostoc commune. It is proposed that Nostoch is a play on two words, an Old English word and a German word, which both describe that part of the human anatomy intimately associated with extracellular polysaccharide; Nosthryl and Nasenloch $=$ Nostoch.
\end{abstract}

The genus Nostoc (cyanobacteria) is one of five genera in the family Nostocaceae of subgroup 4, section A, of the oxygenic phototrophic bacteria (5). Descriptions of Nostoc species can be traced back more than 1,600 years to the time of the Eastern Jin Dynasty (317 to 420 A.D.), when Nostoc commune, known as Ge-Xian-Mi, was used as a staple food by Hung $\mathrm{Ge}$, a renowned alchemist and hermit $(3,7)$. The use of the name Nostoc has its origins in Europe some 500 years ago, well before the scourge of the Black Death in the 1600 s and more than 200 years before Antonie van Leeuwenhoek described animalcules under his prototype microscope in 1702. To understand why the genus Nostoc came to prominence at this time requires the consideration of several facts that have to do with its life cycle. Colonies of many Nostoc species, especially $N$. commune, appear in soils as blackened, brittle, nondescript crusts when they are dried, but become conspicuous and swollen as dark blue-green or olive-green masses, with the consistency of firm gelatin, when they are wetted. The extracellular polysaccharide of these organisms is a complex, high-molecular-weight glycan with unique rheological properties (10). The amount of swelling of a rewetted colony is prodigious, and the process occurs extremely rapidly. Anyone who has handled such material is well aware of the often pungent and characteristic earthy smell due principally to trans-1,10-dimethyltrans-2-decalol, or geosmin (9). Anything that is conspicuous and that has an unusual smell tends to catch people's attention. The rapid appearance of growths of $N$. commune after thundershowers led to the common belief during the Middle Ages that such colonies fell from the sky, and these growths were referred to as "Sternschnuppen" (shooting stars), "...that which we call a falling star, a kind of gelly or slime found oftentimes in the Summer in fields, and meadowes" (4).

The prospect of blue-green jelly falling from the sky caught the interest of the scientist, philosopher, and alchemist Aureolus Philippus Theophrastus Bombastus von Hohenheim (Paracelsus; 1493 to 1541 A.D.), who invented the name Nostoch for this material. Paracelsus was a colorful figure who was renowned not only for his science, but also for the fact that he drank with his students and chased after women. This doctor and natural scientist, far from being a quack, is considered to have been a profound genius (1). He was a savvy individual who was accustomed to the articulation and embellishment of folklore. Paracelsus knew only too well about the fables which people related about "troll's butter," "witch's jelly," and the like and through his writings on alchemy and medicine elevated inconspicuous Nostoch to the position of "species ignis,"

\footnotetext{
*Phone: (540) 231-5745. Fax: (540) 231-9070. E-mail: geordie@vt
}

a peculiar intermediate between the microcosmos and the macrocosmos (8). So persuasive was his teaching that many alchemists connected Nostoch with the "philosopher's stone."

There is considerable controversy surrounding the teachings of Paracelsus, and only sketchy details about his life are available. What is known is that he was an iconoclast with a great distaste for classical Greek and Arabic literature and the rigid authority of the universities of his time. He travelled extensively throughout all of the countries of western Europe, where he actively sought out peasants, old wives, and handicraftsmen, knowing that such people often had knowledge well worth acquiring. Paracelsus most certainly had a knowledge of the English and their folk tales, and although he understood and published works in Latin, "he wrote, as he thought, in German, his mother-tongue" (6).

How and why did Paracelsus come to invent the word Nostoch? One of his especially striking observations provides the clue: "Nostoch... pollution of some plethoricall and wanton Star, or rather excrement blown from the nostrils of some rheumatick planet" (2). This is not the outrageous statement that it may seem; rather, it hides the origin of a word that has, for 500 years, resisted etymological scrutiny. Is not Nostoch an ironic play on two words, in true Paracelsian fashion, by an extremely shrewd and very clever man? An Old English word and a German word both describe that part of the human anatomy intimately associated with extracellular polysaccharide; Nosthryl (nostril) and Nasenloch = Nostoch.

This work was supported by National Science Foundation grant IBN 9513157.

I am grateful to Dieter Mollenhauer for reprints, to Jian-Shen Chen for translation of Chinese literature, and to Noel Krieg for helpful comments.

\section{REFERENCES}

1. Bronowski, J. 1974. The ascent of man. Little and Brown, Boston, Mass.

2. Chariton. 1650. Van Helmont's paradoxes. Transl. Suppl. 98.

3. Chen, J.-S. 1996. Personal communication.

4. French, J. 1650. Chymn: Dict.

5. Holt, J. G., N. R. Krieg, P. H. A. Sneath, J. T. Staley, and S. T. Williams (ed.) 1993. Bergey's manual of determinative bacteriology, 9th ed. Williams and Wilkins Co., Baltimore, Md.

6. Keezer, W. S. 1980. Paracelsus: the mystical critic, p. 76-88. In G. R. Dobson (ed.), Alchemy and Alpha Chi Sigma. Office of the Grand Master of Ceremonies, Alpha Chi Sigma, Indianapolis, Ind.

7. Li, S. C. 1596 . Pen Ts'ao Kang Mu (Chinese pharmaceutical compendium) Reprinted in 1977 by People's Medical Publishing House, Beijing, People's Republic of China.

8. Mollenhauer, D. 1985. Blaualgen der Gattung Nostoc-ihre Rolle in Forschung und Wissenschaftsgeschichte. III. Natur Mus. 115:43-59.

9. Naes, H. 1988. Geosmin production. Methods Enzymol. 167:605-608.

10. Potts, M. 1994. Desiccation tolerance of prokaryotes. Microbiol. Rev. 58: $755-805$. 